Türk Coğrafya Dergisi
Sayı 64: 39-50, istanbul
http://www.tcd.org.tr

Hakemli Makale

Reviwed Article

\title{
llıca (Kahramanmaraş) kaplıcalarında termal turizm odaklı rekreasyon faaliyetleri
}

\author{
Recreation activities based on thermal tourism in Ilıca (Kahramanmaraş) springs
}

\author{
Ersin Kaya SANDAL, Nadire KARADEMIR ${ }^{a}$
}

a) Kahramanmaraş Sütçü İmam Üniversitesi, Fen-Edebiyat Fakültesi, Coğrafya Bölümü.

$\begin{array}{rr}\text { Geliş/Received: } & 28.01 .2015 \\ \text { Kabul /Accepted: } & 30.04 .2015\end{array}$

Sorumlu yazar/Corresponding author (N. KARADEMiR) nadire46@hotmail.com

\begin{abstract}
Öz
Bu çalışma Kahramanmaraş Oniki Şubat ilçe sınırları içerisinde yer alan llıca Kaplıcasının coğrafi yönden incelenmesini yapmak, yöreye gelen turistlerin yöre ile ilgili düşüncelerini belirlemek ve yörenin termal turizm potansiyelini ortaya koymak amacıyla yapılmıştır. Çalışma alanı jeolojik ve jeomorfolojik özellikleri bakımından termal kaynaklar açısından büyük bir potansiyele sahiptir. Çalışmada llıca'ya gelen ziyaretçilerin sosyo-ekonomik durumları incelenmiş, termal turizm çerçevesinde llıca ile ilgili genel düşünceleri nicel araştırma yöntemleri kullanılarak değerlendirilmiştir. Çalışmanın örneklemini yöreye termal turizm amacıyla gelen ziyaretçilerden rassal yöntemle seçilen 243 kişi oluşturmaktadır. Sonuç olarak; katılımcıların \%88'inin llıca'dan memnun kaldığı, \%65'inin llıca'ya ailesiyle geldiği, \%42'sinin dinlenme amacıyla, \%50'den fazlasının dost ve arkadaş tavsiyesiyle ve \%81'inin üç kez ve daha fazla geldiği tespit edilmiştir. Yine ziyaretçilerin \%80'i llıca'da alt yapı problemi olduğunu, \%81'i ise llıca'nın tanıtımının yeterince yapıımadığını ifade etmiştir. Çalışmada yörenin rekreasyon faaliyetleri ve termal turizm açısından önemli bir potansiyele sahip olduğu sonucuna ulaşılmıştır.
\end{abstract}

Anahtar Kelimeler: Kahramanmaraş, Ilıca, termal turizm, Ilıca kaplıcası, rekreaktif faaliyet.

\section{ABSTRACT}

This study was conducted to investigate llica springs' in terms of geography which is located in Kahramanmaraş Onikişubat district boundaries, to determine tourist thoughts about the region, and to demonstrate the thermal tourism potential of the region. The study area has a great potential for thermal resources in terms of geological and geomorphological features. In this study, the socio-economic conditions of the visitors that came to llica was examined and thermal tourism framework general thoughts about llica was assessed using quantitative research methods. The sample group taken from visitors that come to Ilica for thermal tourism is consisted of $\mathbf{2 4 3}$ randomly selected people. Finally it was determined that $88 \%$ of participants were satisfied from the llica springs, $65 \%$ of respondents came with family to llica, $42 \%$ of respondents in order to rest, more than $50 \%$ of the participants have come with friends or friend's recommendation, and $81 \%$ of the participants have come from three or more times. Yet $80 \%$ of respondents stated that there are the infrastructure problems in llica, and $81 \%$ of respondents stated that there is not enough advertising of llica springs. The study shows that the area has a great potential for recreational activities and in terms of thermal tourism.

Keywords: Kahramanmaras, Ilıca, Thermal tourism, Ilıca thermal springs, recreation activities.

\section{GiRiş}

Türkiye de turizm faaliyetleri, zaman içerisinde hem turistlerin istek ve ihtiyaçlarının, hem de sosyal ve ekonomik şartların değişmesine bağlı olarak, çeşitlenmiş ve şekil değiştirmiştir. Şehir hayatından sıkılan insanlar, dinlenmek ve hobilerini tatmin etmek için değişik mekânlar veya rekreasyon alanları aramakta (Çetin, 2011) şehirlerin bunaltıcı havası, kalabalığı ve stres dolu yaşam ortamından uzaklaşmak ve böylece sağlık ve zindelik kazanmak amacıyla doğal tu- rizm potansiyeli olan alanları tatil için tercih etmektedir. Çağımızın trafik ve stres gibi sorunları karşısında sağlığını kaybeden insanların modern tıbbi tedavi yöntemleri dışında alpinizm, klimatizm ve en yaygın olarak da termalizm gibi doğal tedavi yöntemlerini kullanmaları daha sık olarak görülmektedir (İbret, 2007).

Turizm alanında yapılan tüm araştırmalar turizm sektöründeki gelişmelerin artarak süreceğini göstermektedir. 
Çünkü dünyadaki ekonomik gelişme ve değişimler bu durumu destekleyen bir görüntü sergilemektedir (Alaeddinoğlu vd., 2011). Son yıllarda Tüm dünyada olduğu gibi Türkiye'de de kıyı turizmi ile özdeşleşmiş olarak görülen kitle turizmi karşısında farklı ve yeni arayışlar gündeme gelmekte, alternatif turizm giderek gelişmektedir (Soykan, 2003; Özgüç, 2007; Emekli, 2006).

Ülkemiz sağlık turizmi kaynakları bakımından oldukça zengindir. Sadece şifalı su kaynaklarının sayısı, tahminen 2000'i aşar (Ülker, 1988). Klimatizm ve alpinizm faaliyetlerinin yapıldığı turistik potansiyel bölgeleri de eklenirse, ülkemizin sağlık turizmi potansiyeli yönünden, dünyanın zengin birkaç ülkesinden biri olduğu anlaşılmaktadır (Doğanay, 1992 ).

Termal turizm; sağlık turizm faaliyetleri içerisinde yer almakta olup, soğuk ve sıcak mineralli suların sağlık amacıyla içme ve dış tatbiklerde kullanılması, kür uygulaması için turistlerin ulaşım, konaklama, ağırlama gereksinimlerinin karşılanmasını içeren çok yönlü bir turizm çeşididir (Özgüç, 1998; Bulut ve Girgin, 2001; Doğaner, 2001; Doğanay, 2001) Kültür ve Turizm Bakanlığı'nın tanımına göre ise termal turizm, termomineral su banyosu, içme, inhalasyon, çamur banyosu gibi çeşitli türdeki yöntemlerin yanında iklim kürü, fizik tedavi, rehabilitasyon, egzersiz, psikoterapi, diyet gibi destek tedavilerinin birleştirilmesiyle yapılan tedavi uygulamalarının yanı sıra termal suların eğlence ve rekreasyon amaçlı kullanımı ile meydana gelen turizm türüdür (www.turizm.gov.tr).

Günümüzde alternatif turistik ürün çeşitlendirilmesinde termal turizm hızlı bir gelişim göstermekte (Pırnar, 2008; Erdoğan ve Akoğlanoğlu, 2008, Türksoy ve Türksoy, 2010, İlban ve Kaşlı, 2009), turizm faaliyetleri içerisindeki yeri ve önemi gittikçe artmaktadır. Herhangi bir yerin ya da ülkenin turist çekebilme potansiyeli (turizmin temel unsurları ya da turizmin arz kaynakları); çekicilikler, erişim ve konaklamaya bağlıdır. Bunlara turizmin "üç A"sı" da denir (Özgüç,1998). Çekicilikler turizmin yer seçiminde rol oynayan önemli coğrafi faktörlerdir. Bu çekicilikler turistin bir yöreyi ziyaret etme isteğini oluşturmaktadır. İç ve dış turistik aktivitelerin yöneldiği önemli turistik çekim merkezlerinden biri de termal turizm alanlarıdır (Doğanay, 1990).

Türkiye'de, Neojen ve Kuvaterner dönemlerinde meydana gelen kıvrılma ve kırılmalar sonucunda çok sayıda termal kaynak ortaya çıkmıştır. Ülkemiz tektonik yapısından dolayı yoğun bir yayılış alanı gösteren ılıcalar ve çeşitli hastalıkların tedavisinde yararlanılan termal sular bakımından oldukça zengin ve önemli ekonomik potansiyele sahiptir. Daha çok kırıklı yapıların yer aldığı alanlarda dağılış gösteren kaplıca, ılıca, çermik, içmeler ve maden suları tarih boyunca insanların çeşitli şekillerde yararlandığı ve şifa buldukları alanlar olmuştur (Özgen, 2010).

Anadolu'da Hititler döneminden itibaren faydalanılan şifaI s sular, Roma ve Bizans dönemlerinde tedavi ve spor amacıyla yoğun olarak kullanıldığı için, kaplıca turizmi en eski turizm şekli olarak kabul edilebilir (Doğaner, 2001). Türkiye'nin jeolojik özellikleri, termal kaynakları ve bu kaynaklara dayalı turizm faaliyetlerinin artan önemi, Türkiye'de termal turizmin gelişmesine neden olmuştur.

Yurdumuzda çok yaygın olarak bulunan termal suların çıktığı kaynaklara ılıca veya kaplıca denir. Doğanay (2001)’a göre kaynak civarında tesis bulunmayan termal kaynaklara ılıca; hamamlar, konaklama tesisleri, kür yapma bölümleri bulunanlara ise kaplıca denilmesi uygun olur. "Kaplıca" terimi "kapalı ılıca" teriminden gelmektedir ve üzerinde yapı bulunan ılıca demektir. "llıca" terimi ise tedaviye yarayan müessese anlamına gelir (Dirisu,1952).

Kaplıcalar, kişilere doğal yöntemlerle tedavi imkanları sunmalarının yanında onların eğlenmelerini, dinlenmelerini, çeşitli rekreaktif faaliyetlerde bulunmalarını ve alandan farklı hizmetler almalarını sağlayan yerlerdir. Bu bağlamda insanlar kaplıcalarda şehrin stresli ortamlarından uzaklaşıp, sağlık ve zindelik kazanmakta, doğal besinlerle beslenmekte ve doğal tedavi yöntemlerini kullanmaktadır. Bu duruma bağlı olarak Anadolu'nun en eski turizm türü olarak kabul edilen kaplıcalar, son yıllarda diğer şehirlerden gelen ziyaretçilerin tedavi ve spor amacıyla kullandıkları mekânlar haline gelmiştir (Güzel, 2013). Sağlık turizmi içinde değerlendirilen kaplıca turizmi, sıcak ve soğuk maden sularının içilmesini, banyo yapılmasını, çamurun sürülmesini kapsayan su tedavisi dışında dinlenme ve eğlenmeyi de içine alan bir turizm türüdür (Tuncel ve Doğaner, 1980).

Kaplıca sularının, $40^{\circ} \mathrm{C}$ den fazla olanlarına "çok sıcak", $35^{\circ}-40^{\circ} \mathrm{C}$ olanlarına "sıcak", $25^{\circ}-35^{\circ} \mathrm{C}$ olanlarına "ılık", $20^{\circ}$ $25^{\circ} \mathrm{C}$ olanlarına "serin", $20^{\circ} \mathrm{C}$ den az olanlarına "soğuk" kaynaklar denmektedir (www. ekodialog.com, 2013). Termal kaynakların sayısı ve içeriklerinin zenginliği bakımından Türkiye dünyada ilk 10 ülke içinde sayılmaktadır. Türkiye'deki kaplıca suları debi ve sıcaklık, çeşitli fiziksel ve kimyasal özellikleri açısından Avrupa'daki termal sulardan üstündür. Böylece bu sular geniş bir tedavi olanağı yaratmaktadır (Aslan, 1993).

Türkiye tarihi geçmişi, benzersiz doğal kaynakları, iklimi, zengin kültür yapısı ile geleneksel kaplıca ve Türk Hamamı kültürünün varlığı sayesinde, çağdaş sağlık turizminin ve termal turizmin gelişmesinde oldukça büyük bir potansiyele sahiptir. Türkiye termal su kapasitesi açısından Dünyada ilk yedi ülke arasında, Avrupa'da birinci sırada, kaplıca uygulamaları konusunda ise üçüncü sırada yer almaktadır. Türkiye sıcaklıkları 20 ㅇ'nin üzerinde, debileri ise $2-500$ lt/sn arasında değişen 1500 'den fazla kaynağa sahip bulunmaktadır (Kültür ve Turizm Bakanlığı, 2013). Jeotermal kaynak potansiyelinin ancak \% 3 "ünü değerlendirebilen Türkiye'de toplam jeotermal ısı potansiyeli 31.500 MWt"tır. Bu potansiyel 5 milyon konut ısıtma eşdeğeri veya 1 milyonun üzerinde termal yatak kapasitesi anlamına gelmektedir (Kaya, 2003). Türkiye, dünyada jeotermal ısı kullanımı ve kaplıca uygulamalarında Çin, Japonya, A.B.D ve İzlanda'dan sonra dünyanın ilk beş ülkesi içerisinde yer almaktadır (Lund ve Freeston, 2001). Ancak günümüzde kemik, deri ve iç hastalıkları gibi çok sayıda hastalığın tedavisinde yararlanılan bu kaynakların sadece \% 6'sı Türkiye'de sağlık turizminde kullanılmaktadır (Sayılı vd., 2007). 
Türkiye geniş bir alana yayılan zengin termal kaynaklara ve yıl boyunca termal hizmetleri gerçekleştirebilme imkanına sahip olmasına rağmen, ülkemizde termal turizm yeterli derecede değerlendirilememektedir (Erdoğan ve Aklanoğlu, 2008). Türkiye'de termal turizme gereken önemin verilmesi Türk turizmini çeşitlendirecektir. Bu bağlamda Kültür ve Turizm Bakanlığı orta ve uzun vadede termal turizmde ülkemizin dünyanın en önemli sağlık ve termal destinasyonu olması için çalışmalar yapmaktadır. Termal sularımızın sadece insan sağlığını iyileştirmeye yönelik tesisler, rekreasyon, eğlence, dinlenme ve spor tesisleri gibi imkanların yer aldığı ve tüm yıl boyunca hizmet verebilen alanlar haline getirilmesine çalışmaktadır. Çünkü turistik faaliyetlerin bütün yıla yayılması turizm ekonomisi açısından büyük önem taşımaktadır. Günümüzde turizm faaliyetlerinin önemli bir kolu haline gelen termalizm de hem tedavi hem de rekreasyonel faaliyetlere olanak sağlaması ve turistik faaliyetleri bütün bir yıla yayarak, farklı beklentileri olan turistlere hizmet sunabilmesi ise tüm sezon boyu çalışan bir sektör olması açısından önemlidir.

Sağlık sadece hastalıklardan ve mikroplardan korunma değil, bir bütün olarak beden, ruh ve sosyal açıdan iyi olma halidir (Taşlıyan ve Arı 2012). Sağlık turizmi, sağlığı korumak ya da iyileştirmek için belirli bir süre yer değiştiren insanların doğal kaynaklara dayalı turistik bir tesise giderek kür uygulaması gerçekleştirmesi, sıcak su içerisinde banyo yapması, çamur banyosu yapması, konaklama, dinlenme ve eğlence gereksinmelerini karşılamasıdır (Çetin, 2011; Tuncel ve Doğaner, 1992). Kültür ve Turizm Bakanlığı'nın tanımına göre ise; sağıık turizmi tedavi amaçlı kaplıcalara veya diğer sağlık merkezlerine seyahat eden kişilerin, fiziksel iyilik halini geliştirmek için veya estetik cerrahi operasyonlar, organ nakli, diş tedavisi, fizik tedavi, rehabilitasyon vb. gereksinimi olanlarla birlikte, uluslararası hasta potansiyelini kullanarak sağlık kuruluşlarının büyümesine olanak sağlayan turizm türüdür. Bu bağlamda değerlendirildiğinde Kahramanmaraş Onikişubat ilıçe sınırları içerisinde yer alan ve sağlık turizmi açısından önemli bir potansiyeli olduğu düşünülen Ilıca kaplıcası bu araştırmanın konusunu oluşturmaktadır (Şekil 1). Bu çalışmanın amacı ise coğrafi açıdan Ilıca kaplıcasının potansiyelini incelemek, yöreye gelen ziyaretçilerin kaplıca ile ilgili düşüncelerini ortaya koymak ve karşılaşılan sorunlarla ilgili çözüm önerileri sunmaktır.

\section{KONU ve KAPSAM}

Bu çalışmada konuyla ilgili yerli ve yabancı kaynaklar taranmış, ziyaretçilerin kaplıcayla ilgili düşüncelerini ortaya koyabilmek için araştırmacılar tarafından hazırlanan anket uygulaması gerçekleştirilmiştir. Çünkü anket nicel araştırma yöntemleri içerisinde en çok kullanılan veri toplama tekniklerinden birisidir (Ekiz, 2003). Hazırlanan anket sorularının anlaşılır olup olmadığının belirlenmesi için Ilıca'yı ziyaret eden bir grup ziyaretçiye ön anket uygulaması yapılmış, anlaşılmayan sorular anketten çıkarılmış ve anket soruları üzerinde gerekli düzenlemeler yapılarak, veri toplama aracına son şekli verilmiştir. Bu araştırmanın çalışma grubunu 2014 yılı Temmuz ve Ağustos aylarında yani yaz döneminde
Ilıca'yı ziyaret eden ve rassal olarak seçilen ziyaretçiler oluşturmuştur. Anketin değerlendirilmesinde SPSS programı kullanılmıştır. Yöre sakinleri ve bir kısım ziyaretçi ile de mülakat yoluyla bilgiler elde edilmiştir.

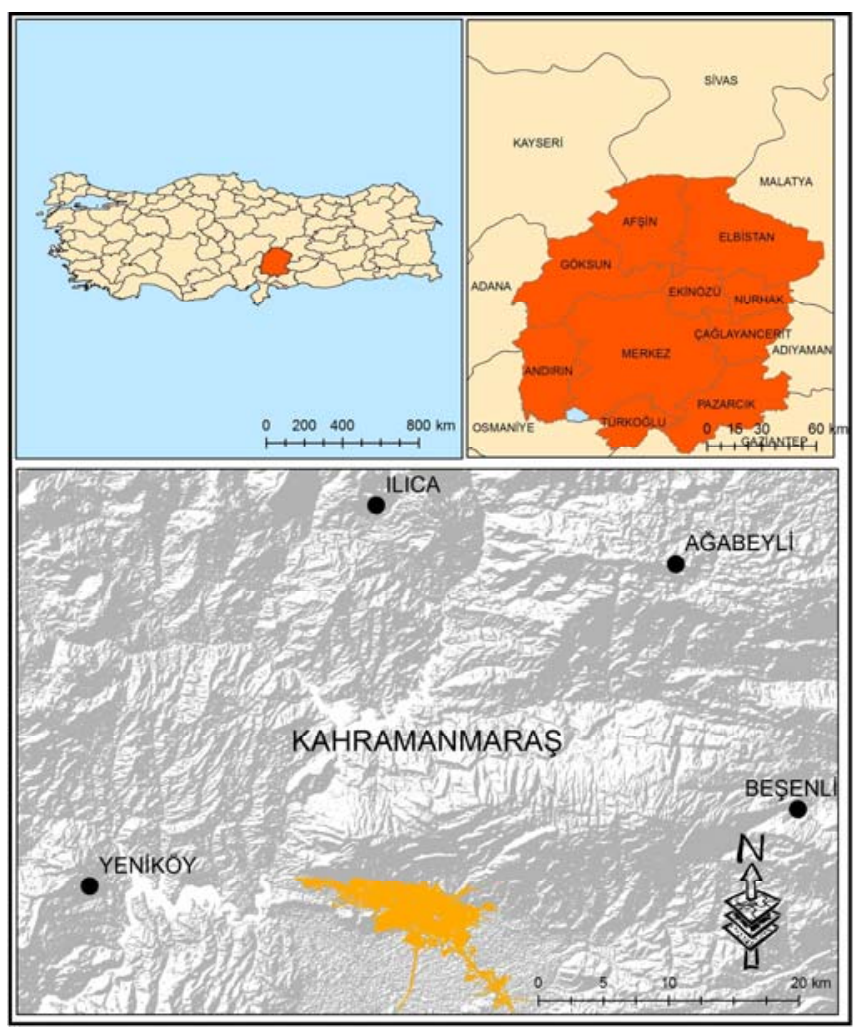

Şekil 1. Çalışma alanının lokasyon haritası.

Figure 1. Location map of the study area.

Bu araştırmada ayrıca ArcMAP 10 programıyla Ilıca'nın coğrafi konumu, jeolojik ve topografik durumunu ortaya koyan haritalar üretilmiştir. Yörenin termal turizm potansiyelini ortaya koyabilmek amacıyla ilgili kurumlar ve llıca Belediyesinden gerekli veriler alınmış ve araştırma bölgesinde arazi çalışmaları yapılmıştır.

\section{BULGULAR ve TARTIŞMA}

\section{Araştırma Alanının Coğrafi Konumu}

Araştırma alanını oluşturan Ilıca Kaplıcası, Akdeniz Bölgesi'nin doğusunda Kahramanmaraş'ın 68 km. kuzeyinde Berit Dağı eteklerinde $1000 \mathrm{~m}$. yükseltide ve llıca yerleşmesi sınırları içerisinde yer almaktadır (Şekil 2).

\section{Jeolojik Özellikler}

Araştırma sahası, Arap Levhası ile Anadolu Levhası'nın çarpışma kuşağında, Anadolu Levhası'nda yer alır. Bu iki levhanın Kretase'de çarpışması ile başlayan kuzey-güney yönlü birçok kıvrılma-kırılma-bindirme ve sürüklenmelerin oluşmasına neden olmuştur. Tersiyer öncesi dönemlerde başlayan ve Miyosen'de gelişmeye devam eden tektoniğe bağlı hareketlerin yoğun olduğu yörede (Gül vd., 2005) Üst Miyosen ve Pliyosen'de kuzeyden güneye doğru olan kompresyonel rejim, Ilıca'nın güneyinden geçen ve çalışma alanını batıdan doğuya kat eden bindirmenin oluşmasına neden 
olmuştur. Bu bindirmeye bağlı olarak Ilıca'nın içerisinden geçen ikinci bir ters fay gelişmiştir. Ilıca termal kaynakları bu Tektonizma ve faylanmanın etkisiyle sahada eğim değerlerinin yüksek olduğu, arızalı bir topografya hâkimdir (Şekil 23).

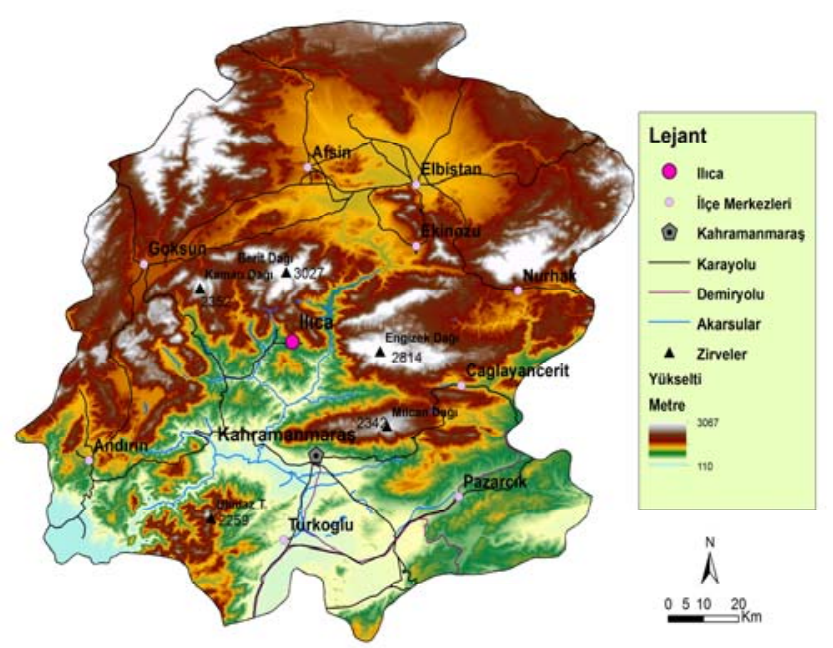

Şekil 2. Çalışma alanı ve yakın çevresinin fiziki haritası.

Figure 2. Physical map of study area and its environs. ters faydan çıkmaktadır (Gürbüz ve Korkmaz, 2001).

\section{İklim Özellikleri}

Yörede kış yağışlarının fazla ve yaz kuraklığı süresinin uzun olduğu Akdeniz makro iklim tipi görülmektedir. Ancak bölgede yükseltiye bağlı olarak iklim elemanlarında ve değerlerinde değişimler görülür. Sahada yıllık ortalama sıcaklıklar yaklaşık $13^{\circ} \mathrm{C}^{\prime}$ dir. Aylık ortalama sıcaklıklar incelendiğinde en sıcak ayın Temmuz, en soğuk ayın ise Ocak ayı olduğu görülmektedir. Yörede yükseltinin 950-1100 m. arasında değiştiği dikkate alındığında araştırma alanında yıllık ortalama sıcaklık değerinin $12^{\circ} \mathrm{C}-14^{\circ} \mathrm{C}$ arasında değiştiği hesaplanmaktadır. Yıllık ortalama yağış miktarı Göksun'da $600.1 \mathrm{~mm}$., Kahramanmaraş'ta ise $733.7 \mathrm{~mm}$.'dir (Tablo 1, Şekil 4). Araştırma alanının bu iki yerleşme arasında olduğu dikkate alındığında sahada ortalama yıllık yağış miktarının da belirtilen değerler arasında olduğunu belirtmek mümkündür. Çalışma sahasında toplam yağışın sadece \%3'ü yaz sezonunda düşmektedir. Yükseltinin ve karasallığın etkisinin artmasına bağlı olarak bu alandaki kış yağışlarının bir kısmı kar şeklinde görülür. Genelde kar yağışları Kasım ayının sonunda başlar ve kar örtüsü yüksek kesimlerde Mart ayına kadar yerde kalır.

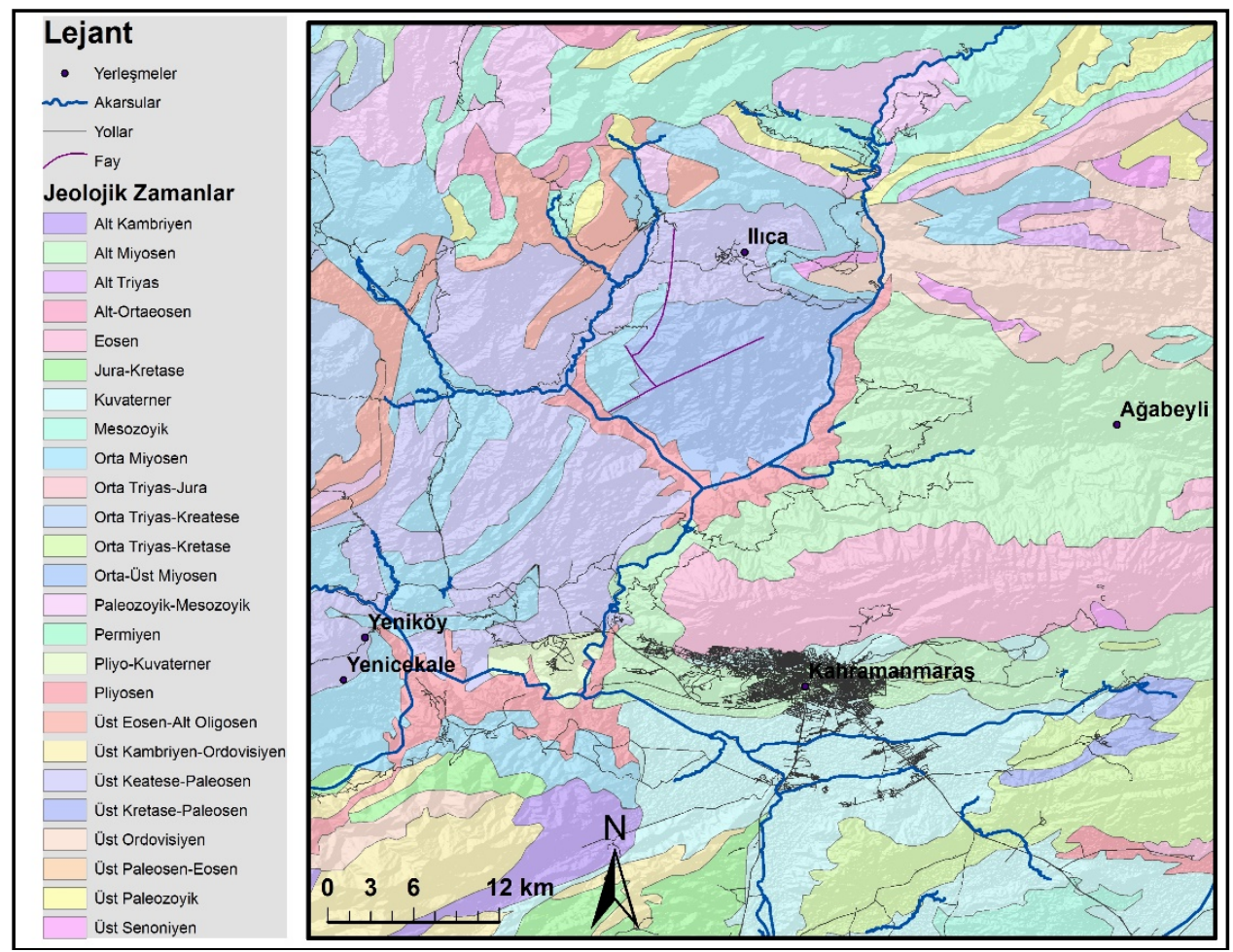

Şekil 3. Çalışma alanı ve yakın çevresinin jeoloji haritası.

Figure 3. Geological map of study area and its environs.

Tablo 1. Kahramanmaraş ve Göksun'un aylık ve yıllık ortalama sıcaklık ve yağış değerlerinin dağılımı.

Table 1. Monthly and annually average temperature and precipitation of Kahramanmaraş and Göksun.

\begin{tabular}{|c|c|c|c|c|c|c|c|c|c|c|c|c|c|c|}
\hline ISTASYON & & 0 & Ş & $M$ & $\mathbf{N}$ & $M$ & H & $T$ & A & $E$ & $E$ & K & A & Yıllık \\
\hline \multirow{2}{*}{ K.MARAŞ } & SIC. $\left({ }^{\circ} \mathrm{C}\right)$ & 4.8 & 6.3 & 10.6 & 15.4 & 20.3 & 25.2 & 28.3 & 28.4 & 25.2 & 19.0 & 11.7 & 6.6 & 16.8 \\
\hline & Yağış (mm) & 129.6 & 114.3 & 96.2 & 75.5 & 41.0 & 6.6 & 1.2 & 0.9 & 7.4 & 46.9 & 85.2 & 128.9 & 733.7 \\
\hline \multirow{2}{*}{ GÖKSUN } & SIC. $\left({ }^{\circ} \mathrm{C}\right)$ & -3.8 & -2.4 & 2.8 & 8.5 & 13.0 & 17.7 & 21.3 & 20.8 & 16.2 & 10.5 & 4.1 & -1.1 & 9.0 \\
\hline & Yağış (mm) & 84.7 & 70.3 & 74.4 & 67.2 & 56.0 & 18.1 & 5.8 & 5.9 & 13.5 & 44.2 & 68.2 & 91.8 & 600.1 \\
\hline
\end{tabular}

Kaynak: DMi, 2014 (1954-2013) (1960-2012). 
Ilıca (Kahramanmaraş) kaplıcalarının termal turizm odaklı rekreasyon faaliyetleri

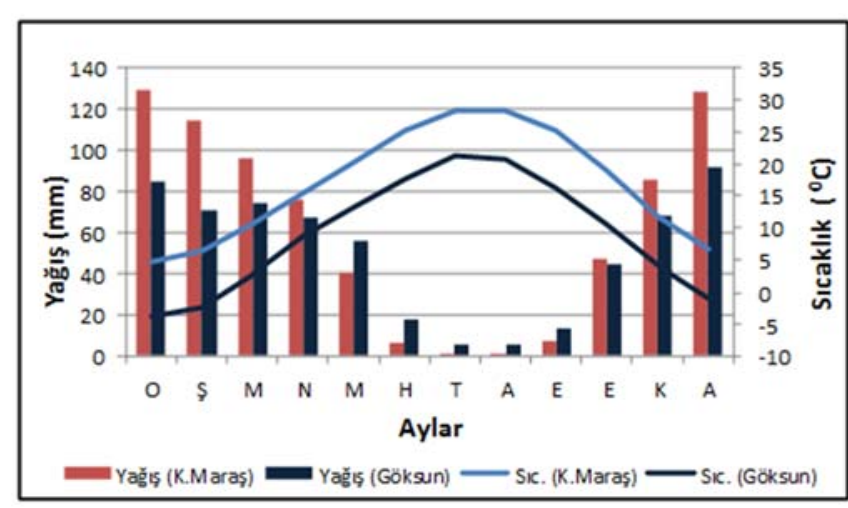

Şekil 4. Kahramanmaraş ve Göksun'un aylık ortalama yağış ve sıcaklık şartları.

Figure 4. Monthly average precipitation and temperature conditions of Kahramanmaraş and Göksun.

Araştırma sahasında özellikle yaz aylarında ortalama sıcaklıkların ve bağıl nem oranının Akdeniz ve Güneydoğu Anadolu bölgesindeki diğer illere göre insanın kendini rahat hissedebilmesi için daha uygun yani düşük olması llıcayı tercih edilir hale getirmektedir. İlim açısından yörenin bağıl nem, sıcaklık, rüzgar, yağış ve güneşlenme bakımından klimatik konfor (iklim konforu) değeri bu iklim değerleri dikkate alındığında oldukça yüksektir (Zengin vd., 2013).

\section{Bitki Örtüsü Özellikleri}

İran-Turan ve Akdeniz bitki coğrafyası bölgelerinin geçiş kuşağında bulunan araştırma alanında, topografya, iklim ve toprak derinliğinde gözlenen farklılaşmalara bağlı olarak zengin bitki tür ve yoğunluğunda değişimler gözlenir. Araştırma sahasında orman alanları geniş yer kaplamakla birlikte, özellikle toprak örtüsünün zayıf olduğu kalkerli zeminler üzerinde kızılçam ve ardıç birlikleri (Juniperus excelsa) geniş sahalara yayılmıştır. Bu birlikteliklere yer yer meşe (Quercus $s p$.) türleri ve tesbih çalısı (Styrax officinalis) eşlik etmekte$\operatorname{dir}(Y ı l d ı z, 2006)$. Sahada otsu bitki türleri kenger (Gundelia tournefortii), geven (Astragalus sp.), sütleğen (Euphorbia $s p$.), sığırkuyruğu (Verbascum sp.), adaçayı (Salvia $s p$ ), çobanyastığı (Acantholimon sp.), kekik (Thymus sp.) de yoğun olarak bulunur. Bitki örtüsünün bu özellikleri yörenin doğal çekiciliğini artırmakta ve Ilıcaya artı bir değer katmaktadır.

\section{Nüfus ve Yerleşme Özellikleri}

Termal kaynaklar bakımından diğer bölgeler kadar zengin olmayan Akdeniz Bölgesinde yer alan Ilıca Kaplıcası (Tıraş, 2004) antik dönemden bugüne kadar çeşitli uygarlıklara hizmet vermiştir. Bölgenin Bizans döneminde Mezopotamya'yı, Orta Anadolu ve İstanbul'a bağlayan yol üzerinde olması da gelişimini hızlandırmıştır. 1886 tarihli (1302) Osmanlı salnamesinde, Zeytun yerleşmesinden ve yerleşmeye yarım saat uzaklıktaki kaplıcadan bahsedilmektedir. Esas itibariyle araştırma sahasının Maraş'tan Elbistan-GürünKayseri ve Elbistan-Malatya'ya giden kervan yolu üzerinde bulunduğu anlaşılmaktadır (Söylemez, 2007). Selçuklular tarafından Zeytun'da bir hamam yaptırılmıştır. Bugünkü Ilıca yerleşmesinde iskan 1880 'lerden itibaren termal kay- nağın bulunduğu dere içerisinde başlamıştır. 1935 yılında 385 nüfuslu bir köy durumunda olan yerleşmenin nüfusu kaplıca kullanımının getirdiği ekonomik canlılık ve potansiyele dayalı olarak devamlı artmıştır. Bugün Ilıca'nın nüfusu 2.600'ü geçmiştir (Tablo 2). Mevcut nüfusun en önemli geçim kaynağını ise termal turizme yönelik ekonomik faaliyetler oluşturmakta ve yaz sezonunda çok sayıda insan çalışmak için yöre dışından buraya gelmektedir.

Tablo 2. Ilıca'nın sayım yıllarına göre nüfus gelişimi.

Table 2. Ilıca population growth by year.

\begin{tabular}{|l|l|l|l|}
\hline Yıl & Nüfus & Yıl & Nüfus \\
\hline 1935 & 385 & 1975 & 1071 \\
\hline 1945 & 434 & 1980 & 1241 \\
\hline 1950 & 570 & 1985 & 2102 \\
\hline 1955 & 676 & 2007 & 2773 \\
\hline 1960 & 784 & 2010 & 2664 \\
\hline 1965 & 860 & 2012 & 2607 \\
\hline 1970 & 887 & 2013 & 2614 \\
\hline
\end{tabular}

\section{Termal Suların Fiziksel ve Kimyasal Özellikleri}

Daha önce de belirtildiği gibi Üst Miyosen ve Pliyosen'de kuzeyden güneye doğru olan kompresyonel rejim, Ilıca'nın güneyinden geçen ve çalışma alanını batıdan doğuya kat eden bindirmenin oluşmasına neden olmuştur. Bu bindirmeye bağlı olarak Ilıca'nın içerisinden geçen ikinci bir ters fay gelişmiştir. Ilıca termal kaynakları bu ters faydan çıkmaktadır. Bu kaynaklar, yüzeysel suların faylara bağlı olarak derine sızarken geçtikleri kayaçların minerallerini eriterek bünyelerine alması, akifer nitelikli kayaçlar içinde toplanmaları ve jeotermal gradyana bağlı ısınarak ters faydan yüzeye çıkması sonucunda oluşmuştur (Gürbüz ve Korkmaz, 2001).

Doğal kaynaklardan biri llıca Dere vadisi içerisindeki ters fay üzerinde bulunan Alt Miyosen kalkerlerindeki mağaradan, diğeri ise Özel İdare Hamamı'nın hemen kuzeyinden çıkmaktadır. 1991 yılında açılan ve faal olan Süleymanlı 2 adındaki kuyu günümüzdeki ihtiyacın çok az bir kısmını karşılayabilmektedir. Bu kuyunun derinliği 437,85 m., debisi $14 \mathrm{lt} / \mathrm{sn}$. sıcaklığı ise 43,5으 dir. 2004 yılında K1-4 ve K1-5 adlarında iki yeni kuyu daha açılmıştır. Bu kuyulardan K1-4 kuyusunun derinliği $278 \mathrm{~m}$. olup debisi $25 \mathrm{lt} / \mathrm{sn}$ sıcaklığı ise 49 ㅇ C dir. K1-5 kuyusunun derinliği $407 \mathrm{~m}$. olup debisi 30 It/sn sıcaklığı ise 49ㅇ dir. Bu iki kuyu halen kullanılmakta ve ihtiyacın bir kısmını gidermektedir. Son kuyu 2007 yılında özel Özger Otelin bahçesine 575 m. derinliğinde açılmıştır. Bu kuyunun debisi 10 It/sn ve su sıcaklığı 41ㅇC dir (Kahramanmaraş Valiliği (Yikob), 2014).

Ilıca termal kaynaklarının sıcaklığı mevsime göre genellikle 41-49으 arasında değişmektedir. Buna göre Ilıca termal kaynakları 'hipertermal sular" (40-50ㄷ) grubuna girmektedir. Ilıca termal sularının pH değeri Çakar'a (1996) göre 77.5 arasında değişir. Bu değerler itibarıyla olumlu ve yarı olumlu bazik sular grubuna girer. Ilıca termal kaynakları, kimyasal bileşenleri bakımından bikarbonatlı $\left(\mathrm{HCO}_{3}\right)$, kalsiyumlu (Ca), kükürtlü (S), ve magnezyumlu (Mg); fiziksel olarak ise hipertermal sulardır (Ülker, 1988; Ilıca Belediyesi 
(www.ilica.bel.tr), 2014; Tablo 3). Ilıca Kaplıcası Sağlık Bakanlığı tarafından 2002 yılında 24675 sayılı yazıyla kaplıca statüsüne alınmıştır.

Ilıca termal sularından genelde banyo yaparak (dıştan tedavi) ve az da olsa içerek (içten tedavi ) yararlanılmaktadır. Ilıca termal suları, Sağlık Bakanlığı, Refik Saydam Hıfzısıhha Merkezi'nin analiz raporuna göre romatizmal, fonksiyonel damar, solunum sistemi, sinir sistemi, deri, kronik bronşit, üst solunum yolları ve kadın hastalıkları gibi hastalıkların tedavisinde kullanılmaktadır. Tedavinin olumlu sonuç verebilmesi için genellikle en az 5 gün (günde en çok üç defa banyo ve her banyo süresi 15 dakikayı geçmemeli) termal tesislerden yaralanmak gerekir. Kaplıcada doktor sevkli gelen hastaların tedavilerinin masrafları, bağı bulunduğu kurum tarafından ödenmek suretiyle karşılanmaktadır.
Ayrıca yörenin bol oksijenli havası, insanların solunum yollarını rahatlatıcı ve kan dolaşımını hızlandırıcı etki yapmaktadır. Yöreye gelen ziyaretçiler gezme, eğlenme, dinlenme amaçlı faaliyetlerde de bulunmaktadır.

Ilıca kaynaklarından çıkan suların değerlendirildiği modern tesisler 1957 yılından itibaren yapılmaya başlanmıştır. illk tesis 1957 yılında mağaradan çıkan sıcak su kaynakları üzerine inşa edilmiş ve 1980 yılına kadar aktif olarak kullanılmıştır. Ancak artan taleplere cevap veremediğinden aynı yıl il Özel idaresi tarafından bu alanda modern bir termal hamam yaptırılmıştır. 1980'de yaptırılan bu hamam, baylar ve bayanlar için iki yüzme havuzu, iki kür havuzu, üç aile banyosu, dört özel küvet ve bir Türk hamamı bölümlerinden oluşmakta, aynı anda 400 kişi yararlanabilmekte ve hamamın günlük kapasitesi 4.000 kişiyi bulmaktadır.

Tablo 3. Ilıca'da bulunan termal suların kimyasal özellikleri.

Table 3. Chemical properties of thermal waters in Ilıca.

\begin{tabular}{|c|c|c|c|c|c|c|}
\hline Kaynak & \multicolumn{3}{|c|}{ Sondaj kuyusu } & \multicolumn{3}{|c|}{ Dere kaynağı } \\
\hline Sıcaklık (으) & \multicolumn{3}{|l|}{43} & \multicolumn{3}{|l|}{41} \\
\hline Debi (It/sn) & \multicolumn{3}{|l|}{2.21} & \multicolumn{3}{|l|}{3.44} \\
\hline Berraklık & \multicolumn{3}{|c|}{ Canlı ve demir tortulu } & \multicolumn{3}{|c|}{ Canlı ve demir tortulu } \\
\hline Katyonlar & $\mathrm{mg} / \mathrm{lt}$ & milival/lt. & \%milival & $\mathrm{Mg} / \mathrm{lt}$ & milival/lt & \%milival \\
\hline Potasyum (K) & 1.3 & 0.03 & 0.68 & 1.1 & 0.03 & 0.70 \\
\hline Sodyum & 17 & 0.74 & 16.86 & 15 & 0.65 & 15.33 \\
\hline $\mathrm{NH}_{4}$ & 0 & 0 & 0 & 0 & 0 & 0 \\
\hline Kalsiyum (Ca) & 33.7 & 1.68 & 38.27 & 34.5 & 1.72 & 40.57 \\
\hline Magnezyum (Mg) & 23.6 & 1.94 & 44.19 & 22.4 & 1.84 & 43.40 \\
\hline Demir (Fe) & $<0.1$ & & & $<0.1$ & & \\
\hline B (total) & 0.2 & & & 0.2 & & \\
\hline Toplam & 75.9 & 4.39 & 100 & 73.3 & 4.24 & 100 \\
\hline \multicolumn{7}{|l|}{ Anyonlar } \\
\hline Bikarbonat $\left(\mathrm{HCO}_{3}\right)$ & 201 & 3.30 & 72.85 & 201 & 3.30 & 74.57 \\
\hline Karbonat $\left(\mathrm{CO}_{3}\right)$ & 9 & 0.30 & 6.62 & 0 & 0 & 0 \\
\hline Sülfat $\left(\mathrm{SO}_{4}\right)$ & 28 & 0.58 & 12.80 & 30 & 0,62 & 14.59 \\
\hline Klorür (Cl) & 12 & 0.35 & 7.73 & 14 & 0.39 & 9.4 \\
\hline İyodür (I) & 0 & 0 & 0 & 0 & 0 & 0 \\
\hline Flüorür (F) & 0.53 & & & 0.53 & & \\
\hline Sülfit (S) & $<0.1$ & & & $<0.1$ & & \\
\hline Toplam & 250.63 & 4.53 & 100 & 245.63 & 4.31 & 100 \\
\hline \multicolumn{7}{|l|}{ Diğer Elementler } \\
\hline Karbondioksit $\left(\mathrm{CO}_{2}\right)$ & 1.08 & & & 0.02 & & \\
\hline $\mathrm{pH}$ & 8.5 & & & 8.2 & & \\
\hline Spesifik Konduktivite & 390 & & & 420 & & \\
\hline Spesifik gravite & 1000 & & & 1000 & & \\
\hline Buharlaşma kalıntısı & 280 & & & 270 & & \\
\hline Toplam & 1.02 & & & 2.02 & & \\
\hline Genel toplam & 327.55 & & & 320.95 & & \\
\hline Suyun sınıflandırılması & \multicolumn{3}{|c|}{ Mineralce fakir "Akrotora" sıcak } & \multicolumn{3}{|c|}{ Mineralce fakir "Akrotora" } \\
\hline
\end{tabular}

Kaynak: http://www.ilica.bel.tr_2014. 
Ilıca (Kahramanmaraş) kaplıcalarının termal turizm odaklı rekreasyon faaliyetleri

Yine Ilıca Belediyesi tarafından 1998 yılında yeni bir hamam (Vali Saim Çotur Kaplıcası) yaptırılmıştır (Fotoğraf 1). Bu hamam bay ve bayan olmak üzere 7x12 m ebadında, üstü kapalı iki kür havuzu, 10x6 m. ebadında üstü açık iki yüzme havuzu, iki Türk Hamamı, buhar banyosu, beş sağlık havuzu (jakuzi havuz) ve duşlardan oluşmaktadır. Bu hamamın aynı anda toplam kapasitesi 500-600 kişi iken günlük kapasitesi 3000-4000 kişiyi bulmaktadır (Ilıca Belediyesi, 2014). Yörede kaynak sularına sahip diğer tesis ise Özel Özger Termal Otelidir. Bu otelde her odaya termal su verilmekte ve ayrıca ziyaretçilerin kullanabileceği jakuzi, restoran, spor ve oyun salonları bulunmaktadır.

Ilıca'nın bulunduğu bölgenin iklimi, sağıı turizmini geliştirmeye elverişli bir durumdadır. Ilıca Belediyesinden alınan bilgilere göre, hava şartlarının uygunluğuna ve okulların tatil olmasına bağlı olarak turizm mevsimi Nisan ortasından Kasım ortasına kadar 7 ay sürmektedir. Mayıs ayından itibaren turistler kaplıcaya gelmeye başlamakta ve Kasım ayına kadar yoğunluk devam etmektedir. Temmuz, Ağustos ve Eylül ayları en yoğun dönem olup, bu üç aylık dönemde hem kaplıcalarda hem de yörede bulunan apart ve otel tarzı evlerde doluluk oranı \%90'ı aşmakta, diğer aylarda \%20-30 dolayında gerçekleşmektedir. Eylül ayında okulların açılmasından sonra ziyaretçi sayısında bir miktar düşüş yaşansa da günümüzde otel, motel, pansiyon ve apartlarda kalorifer düzeneğinin olmasıyla kış aylarında dahi turistlerin gelişleri devam etmektedir. Ilıca'da ortalama konaklama süresi 3-15 gün arasında değişmektedir. Termal tesisler 05:00 ile 22:00 saatleri arasında açık bulunmakla birlikte Ramazan ayında geceleri sahura kadar da hizmet vermektedir.

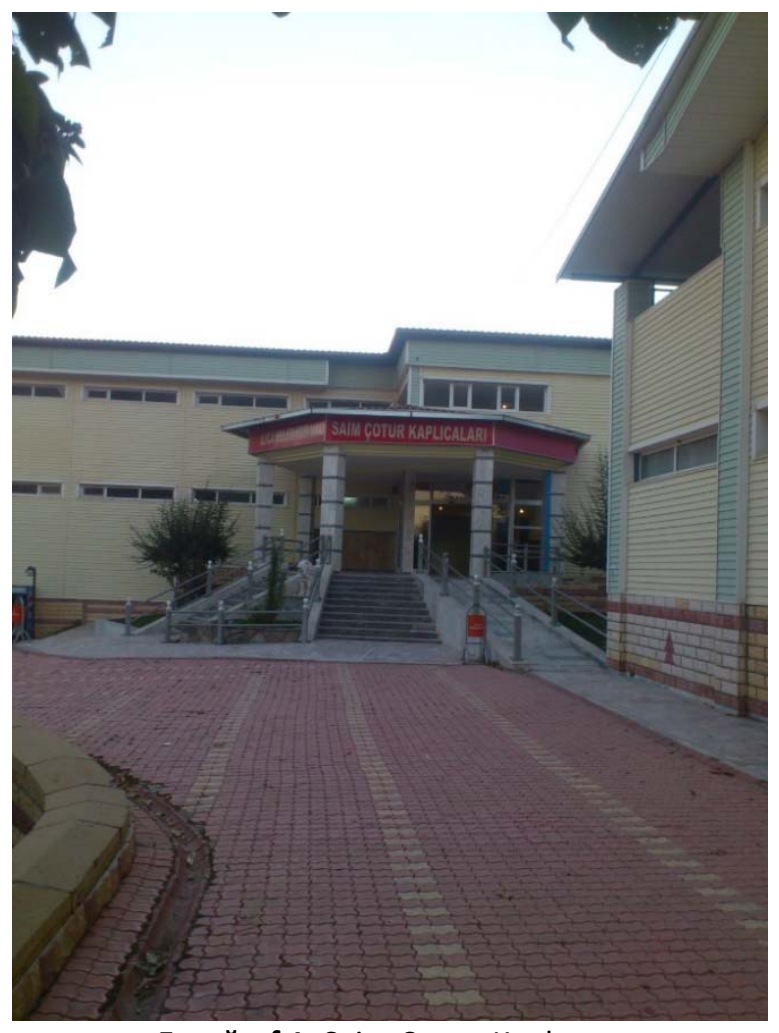

Fotoğraf 1. Saim Çopur Kaplıcası.

Photo 1. The view from Saim Çopur Thermal.
Ilıca kaplıcasında 2014 yılı verilerine göre 120 adet otel, motel ve pansiyon bulunmaktadır (Tablo 4). Bunların toplam yatak kapasitesi ise 3000 civarındadır. Ayrıca yöre sakinleri evlerini belli zaman aralıklarında kiraya vermekte ve böylece yatak kapasitesi daha da artmaktadır. Yaz sezonunda Ilıca'daki günlük nüfus hareketi 10 bini geçmektedir. Çünkü bu dönemde öncelikle Kahramanmaraş şehir merkezi olmak üzere Gaziantep, Şanlıurfa, Adana, Osmaniye, Hatay, Adıyaman, Malatya, Mardin, Diyarbakır, Siirt, İstanbul ve daha birçok ilden hatta yurt dışından binlerce insan hem kaplıcadan yararlanmak hem de tatillerini burada geçirip dinlenmek için Ilıca'ya gelmektedir. Güzel ve diğerleri (2013) de çalışmasında özellikle yaz döneminde gerek dinlenme gerekse tedavi amacıyla Şanlıurfa'dan, Yalova, Afyonkarahisar ve Kozaklı dışında Kahramanmaraş Ilıca kaplıcalarına da her yıl binlerce insan gittiğini belirtmektedir.

Ilıca'ya gelen turistlerin beslenme ihtiyaçlarının karşılanması, yöre halkı için önemli bir gelir kaynağı oluşturmaktadır. Yörede üretilen bitkisel (sebze, meyve) ve hayvansal ürünler (süt, yoğurt) turistler tarafından tüketilmekte ve dolayısıyla yöre halkı tarafından işletilen işletmeler gelir elde etmektedir. Ilıca'da 10 kasap, 11 fırın, 10 manav, 11 bakkal, 11 çay ocağı, 15 manifatura, 10 hediyelik eşya, 4 pastane başta olmak üzere çok sayıda işletme bulunmaktadır (Tablo 4). Bu işletmelerde yüzlerce insan istihdam edilmekte ayrıca Belediye tarafından işletilen tesislere de yaz sezonunda onlarca geçici işçi alınmaktadır.

Tablo 4. Ilıca'da bulunan işletmeler.

Table 4. Businesses in Ilıca.

\begin{tabular}{|l|l|l|l|}
\hline Tesis Adı & Sayısı & Tesis Adı & Sayısı \\
\hline Otel ve Pansiyon & 120 & Kahvehane & 3 \\
\hline Manifatura & 15 & Tüpçü & 3 \\
\hline Bakkal & 11 & Boyacı & 2 \\
\hline Çay ocağı & 11 & Camcı & 2 \\
\hline Pide Fırını & 11 & $\begin{array}{l}\text { Güneş Enerjisi } \\
\text { İmalathanesi }\end{array}$ & 2 \\
\hline Açık Pazar & 10 & Otomobil Tamircisi & 2 \\
\hline Kasap & 10 & Sıcak-Soğuk Demirci & 2 \\
\hline $\begin{array}{l}\text { Zücaciye ve } \\
\text { Hediyelik Dükkanı }\end{array}$ & 10 & Sıhhi tesisat & 2 \\
\hline Berber & 5 & Eczane & 1 \\
\hline Lokanta & 5 & Lunapark & 1 \\
\hline Çay Bahçesi & 4 & Petrol & 1 \\
\hline Kaffe ve Pastane & 4 & Somun Fırını & 1 \\
\hline
\end{tabular}

\section{Anketlerin Değerlendirilmesi}

Çalışmanın bu bölümünde ziyaretçilerin kaplıca ile ilgili düşüncelerini ortaya koyan anket sonuçları değerlendirilmiş ve elde edilen bulgular aşağıda belirtilmiştir.

Katılımcıların \% 69,1'u erkek, \%30,9' u kadındır. Bu katıIımcıların \% 73,3 evli, \% 26,7'si bekârdır (Tablo 5). Anketi cevaplandıranların \%4,5'i 18-24 yaş aralığında, \%45,7'i 2545 yaş aralığında, \%30’u 46-60 yaş aralığında, \%19,8'i ise 61 yaş ve üzeridir (Şekil 5). Araştırmaya katılanların \%70’ye 
yakınının erkek olması, erkeklerin ailelerinin dışında hemcinsleri ile kısa süreli de olsa Kahramanmaraş ve çevresinden dinlenmek ve eğlenmek amacıyla Ilıcaya gitme kültüründen kaynaklanmaktadır. Bunun yanında $\% 75^{\prime}$ inden fazlasının 25-60 yaş arası olması llıca'yı yükseköğretim çağı üzerindeki yetişkin yaş kesiminin hem sağlığını iyileştirmek hem de hem dinlenmek ve eğlenmek amacıyla gelmelerinden kaynaklanmaktadır. Ziyaretçilerin \%20'ye yakınını da 61 yaş ve üzeri yani asıl sağlık problemleri nedeniyle gelenler oluşturmaktadır.

Katılımcıların, \%25,1'i ilkokul mezunu, \%8,6'sı ortaokul mezunu, \% 24,7'si lise mezunu, \% 29,2'si yüksekokulüniversite mezunu iken \% 12,3'ü okuryazar değildir. Yine katılımcıların \%18,1'i emekli, $\% 11,9$ 'u işçi, $\% 19,3^{\prime}$ ü memur,\% 23,9'u serbest meslek sahibi, \% 12,8'i esnaf ve \%14'ü ev hanımıdır (Tablo 6). Ayrıca katılımcıların \%23'ü 900 lira ve altı, \% 37,9'u 901-1500 lira arası, \% 14,8'i 15012500 lira, \%21,8'i 2501-3000 lira ve \% 2,5'u ise 3001 lira ve üzeri gelir seviyesine sahiptir (Tablo 6). Katılımcıların büyük kısmının aylık gelir seviyesi 3000 liranın altındadır. Bu gelir seviyesinin üzerinde olanların kaplıcaya gelme oranı ise ancak \%2,5'dir. Kaplıcadan yararlanan yüksek gelir grubuna sahip insanların az olması, var olan tesislerin bu insanların ihtiyacına cevap veremiyor olmasını göstermektedir. Kaplıcaya gelenlerin $\% 50$ 'den fazlasının lise ve üniversite mezunu olması, eğitim seviyesi açısından yüksek olan insanların Ilıca'yı tercih ettiğini göstermesi açısından önemlidir.

Araştırmaya katılanların \%54,3'ü dost-arkadaş tavsiyesi ile \% 0,4'ü radyo-TV aracılığı ile \% 0,8'i katalog ve broşür tanıtımları ile \%11,9"u doktor tavsiyesi ile \%0,8'i gazeteler aracılığı ile \% 31,7'i ise daha önceden kendi tecrübeleri ile llıca'ya geldiklerini ifade etmişlerdir. Yine katılımcıların \%13,6 sağlık sevki ile \%8,6 refakatçi olarak, \%35,8'i termal suyun sağlığına yararlı olduğu için,\% 42'si ise dinlenme amacıyla Ilıca'ya gelmiştir (Tablo 7). Katılımcıların \%50'den fazlasının dost ve arkadaş tavsiyesi ile Ilıca'yı tercih etmiş olmaları, ziyaretçilerin genellikle yöreden memnun bir şekilde ayrılmış olduklarının en önemli göstergelerindendir. Katılımcıların \%75'den fazlası llıca'ya dinlenme ve termal suyun sağlığa yararlı olduğunu düşündükleri için gelmektedirler. Dinlenmek için kaplıcaya gelenlerin oranının diğerlerinden yüksek olması (\%42) insanların burayı bir rekreasyon alanı olarak algıladıklarını göstermektedir.

Tablo 5. Katılımcıların cinsiyet ve medeni durumu.

Table 5. Gender and marital status of participants.

\begin{tabular}{|l|l|l|}
\hline Cinsiyet & $\mathbf{n}$ & $\mathbf{\%}$ \\
\hline Erkek & 168 & 69,1 \\
\hline Kadın & 75 & 30,9 \\
\hline Toplam & 243 & 100,0 \\
\hline Medeni durum & $\mathbf{n}$ & $\mathbf{\%}$ \\
\hline Evli & 178 & 73,3 \\
\hline Bekâr & 65 & 26,7 \\
\hline Toplam & 243 & 100,0 \\
\hline
\end{tabular}

Tablo 8'de belirtildiği gibi katılımcıların \%17,7'si yürüme güçlüğü, \%24,3'ü romatizma hastalıklarını, \% 2,1'i böbrek hastalıklarını, \% 0,8'i mide hastalıklarını, \% 4,5'i cilt hastalıklarını ,\% 7,4'ü psikolojik rahatsızlıklarını tedavi etmek amacıyla Ilıca'ya geldiklerini belirtmişlerken, \% 43,2'si ise dinlenme ve değişiklik amaçlarla Ilıca'ya geldiklerini belirtmişlerdir (Tablo 8).

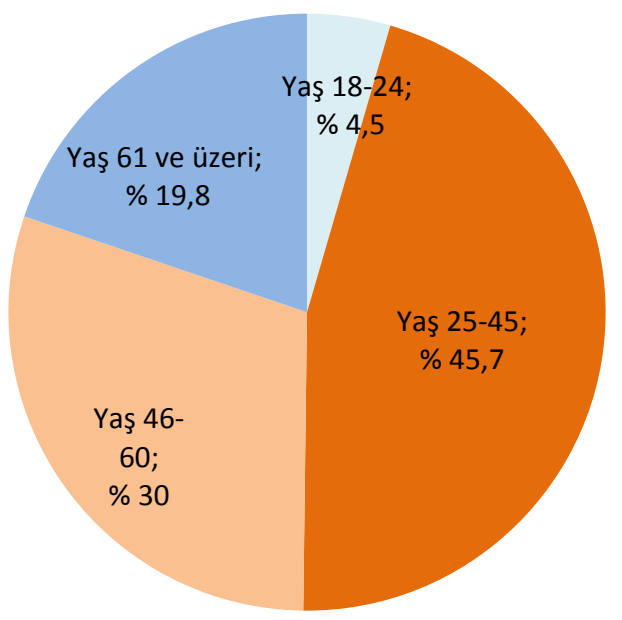

Şekil 5. Katılımcıların yaş gruplarına göre dağılımı.

Figure 5. The distribution of age groups of participants.

Tablo 6. Katılımcıların eğitim, meslek ve aylık gelir durumu. Table 6. Education, occupation and monthly income status of participants.

\begin{tabular}{|l|l|l|}
\hline Eğitim durumu & $\mathbf{n}$ & $\mathbf{\%}$ \\
\hline Okuryazar değil & 30 & 12,3 \\
\hline Illkokul & 61 & 25,1 \\
\hline Ortaokul & 21 & 8,6 \\
\hline Lise & 60 & 24,7 \\
\hline Yüksekokul-Üniversite & 71 & 29,2 \\
\hline Toplam & 243 & 100,0 \\
\hline Meslek durumu & $\mathbf{n}$ & $\%$ \\
\hline Emekli & 44 & 18,1 \\
\hline İşi & 29 & 11,9 \\
\hline Memur & 47 & 19,3 \\
\hline Serbest meslek & 58 & 23,9 \\
\hline Esnaf & 31 & 12,8 \\
\hline Ev hanımı & 34 & 14,0 \\
\hline Toplam & 243 & 100,0 \\
\hline Aylık Gelir Durumu & $\mathbf{n}$ & $\%$ \\
\hline 900 altı & 56 & 23,0 \\
\hline $901-1500$ & 92 & 37,9 \\
\hline $1501-2500$ & 36 & 14,8 \\
\hline $2501-3000$ & 53 & 21,8 \\
\hline 3001 ve üzeri & 6 & 2,5 \\
\hline Toplam & 243 & 100,0 \\
\hline
\end{tabular}

llıca'ya gelenlerin \% 47,7'sini Kahramanmaraş'tan, \% 1,6'sını Mardin'den,\% 1,2'sini Diyarbakır'dan, \% 3,3'ünü Mersin'den,\% 6,6'sını Urfa'dan \%,3,7'sini Osmaniye'den, \% 8,2'sini Adıyaman'dan, \%15,2'sini Gaziantep'ten, \% 4,5'ini Adana'dan, \%7'sini Malatya'dan, \% 0,8'ini İstanbul'dan gelenler oluşturmaktadır (Şekil 6). 
Tablo 7. Katılımcıların Ilıca'ya kimin tavsiyesi ille gelindiği ve geliş amacı.

Table 7. Participants' arrival purpose and recommendation condition.

\begin{tabular}{|l|l|l|}
\hline Kimin tavsiyesi ile geldiği & \multicolumn{1}{|c|}{$\mathbf{n}$} & \multicolumn{1}{|c|}{$\%$} \\
\hline Dost-arkadaş & 132 & 54,3 \\
\hline Radyo-TV & 1 & 0,4 \\
\hline Katalog-broşür & 2 & 0,8 \\
\hline Doktor Tavsiyesi & 29 & 11,9 \\
\hline Gazete & 2 & 0,8 \\
\hline Daha önceki tecrübe & 77 & 31,7 \\
\hline Toplam & 243 & 100,0 \\
\hline Geliş amacı & $\mathbf{n}$ & $\mathbf{\%}$ \\
\hline Sağlık sevki & 33 & 13,6 \\
\hline Refakatçi olarak & 21 & 8,6 \\
\hline Termal sudan faydalanmak için & 87 & 35,8 \\
\hline Dinlenme & 102 & 42,0 \\
\hline Toplam & 243 & 100,0 \\
\hline
\end{tabular}

Tablo 8. Katılımcıların Ilıca'ya tedavisi için geldikleri hastalıklar.

Table8. Participants that they come to Ilıca for the the treatment of these diseases.

\begin{tabular}{|l|l|l|}
\hline $\begin{array}{l}\text { Katılımcıların tedavisini görmek için } \\
\text { geldikleri hastalıklar }\end{array}$ & $\mathbf{n}$ & \% \\
\hline Yürüme güçlüğü & 43 & 17,7 \\
\hline Romatizma & 59 & 24,3 \\
\hline Böbrek & 5 & 2,1 \\
\hline Mide & 2 & 0,8 \\
\hline Cilt & 11 & 4,5 \\
\hline Psikolojik & 18 & 7,4 \\
\hline Hastalılığı iyileştirmek amaçlı değil & 105 & 43,2 \\
\hline Toplam & 243 & 100,0 \\
\hline
\end{tabular}

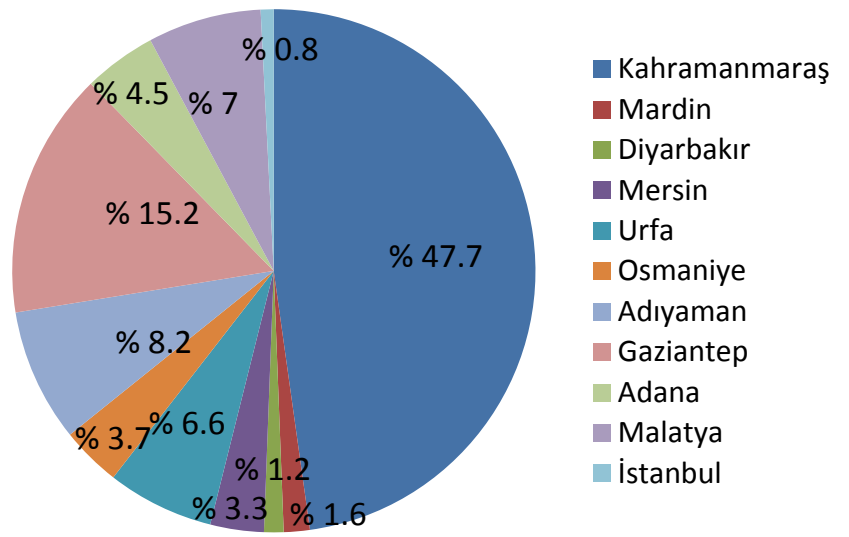

Şekil 6. Katılımcıların geldikleri illere göre dağılımı.

Figure 6. The distribution of participants according to the province they come.

Araştırmaya katılanların \% 40'dan fazlasının hastalığını tedavi etmek için değil, değişik bir ortamda bulunma ve dinlenme amacıyla Ilıca'yı tercih etmişlerdir. Bu durum yörenin termal sularından faydalanmanın yanı sıra rekreak- tif faaliyetler için de kullanıldığını göstermektedir. Katılımcıların \%45'den fazlasının Kahramanmaraş'tan, \%15'inin ise Gaziantep'ten gelmiş olması yörenin yakın çevreden ziyaretçi çektiğini göstermektedir. Ayrıca llıca'daki termal tesislerin bulunduğu ilde ve çevre illerde tanındığını ortaya koymaktadır.

Ilıca'yı seçmelerinin nedeni olarak çalışmaya katılanların \%34,2'si Ilıca'nın bulundukları şehre yakınlığını, \%18,5'i iklim özelliklerinin uygun olmasını, \% 20,2'si akrabalarının burada evlerinin bulunmasını, \%5,3'ü ekonomik olmasını, \%2,5'i ulaşımın kolay olmasını, \%18,5'i termal suyun özelliğini ve \%0,8'i sağlık hizmetlerinin bulunmasını göstermiştir (Tablo 9). Katılımcıların bir termal tesise \% 6,2'si ilk defa, \%12,3'ü ikinci kez, \% 81,5'i üçüncü kez ve fazla geldiklerini söylemişlerdir (Şekil 7). Ankete katılanların \% 3,3'ü Ilıca'da bir gün, \% 22,2'si sadece hafta sonları yani 2 gün, $\% 42,8^{\prime} i$ 3-7 gün, \%20,6'sı 8-14 gün, \%11,1'i ise 15 ve daha fazla gün kaldıklarını belirtmişlerdir (Tablo 9).

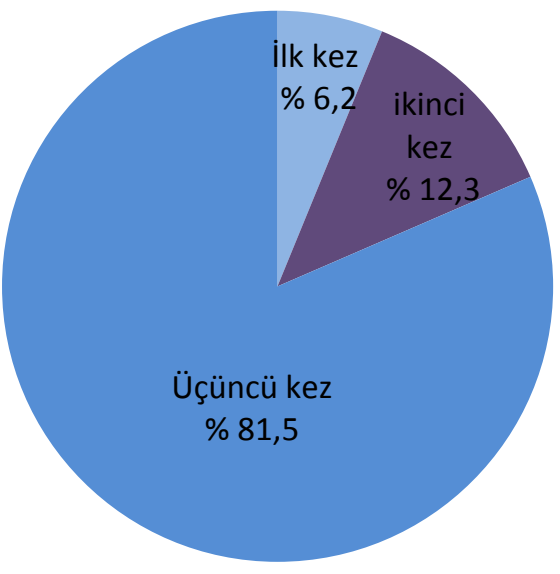

Şekil 7. Katılımcıların Ilıca'ya geliş sayısı

Figure 7. The number of visits made by participants.

Tablo 9. Katılımcıların Ilıca'yı seçme nedenleri, geliş sayısı ve kalma süresi.

Table 9. Participation's choose reasons, arrival number, length of stay.

\begin{tabular}{|l|l|l|}
\hline Ilıca'yı seçme nedenleri & $\mathbf{n}$ & $\mathbf{\%}$ \\
\hline Yakınlık & 83 & 34,2 \\
\hline İklim özellikleri & 45 & 18,5 \\
\hline Akraba evlerinin bulunması & 49 & 20,2 \\
\hline $\begin{array}{l}\text { Tatil yapmak için Ilıca'nın uygun } \\
\text { olması }\end{array}$ & 13 & 5,3 \\
\hline Ulaşım kolaylığı & 6 & 2,5 \\
\hline Termal suyun özelliği & 45 & 18,5 \\
\hline Sağlık hizmetlerinin bulunması & 2 & 0,8 \\
\hline Toplam & 243 & 100,0 \\
\hline Kalma süresi & $\mathbf{n}$ & $\%$ \\
\hline 1 gün & 8 & 3,3 \\
\hline 2 gün & 54 & 22,2 \\
\hline 3-7 gün & 104 & 42,8 \\
\hline 8-14 gün & 50 & 20,6 \\
\hline 15 ve daha fazla & 27 & 11,1 \\
\hline Toplam & 243 & 100,0 \\
\hline & & \\
\hline
\end{tabular}


Tercih nedeni olarak termal suyun özelliğinin \%18,5 gibi düşük bir oranda olması, bunun yanında yakınlık, akraba evlerinin bulunması ve iklim özelliklerinin tercih için daha ön sıralarda olması yöredeki termal suyun yeterince tanıtılamadığının göstergesidir. Ayrıca akraba evlerini tercih edenlerin de oranları küçümsenmeyecek kadar fazla (\% 20,2 ) olması, Kahramanmaraş ve çevresinde tatil anlayışında Ilıca'ya gitme kültürünün varlığını göstermektedir. Katılımcıların \%81,5 gibi büyük bir oranda yöreye üç defadan daha fazla gelmiş olmaları ve $\% 42,8$ gibi bir oranda $3-7$ gün kalmaları memnuniyetlerini göstermesi bakımından önemlidir.

Araştırmaya katılanların \% 67,9'u kaplıcayı diğer insanlara tavsiye edeceğini, \% 9,9'u tavsiye etmeyeceğini, \% 22,2 'si ise kısmen tavsiye edebileceğini ifade etmişlerdir (Tablo 10). Katılımcıların \% 48,6'sı Ilıca'dan memnun kaldıklarını ifade ederken, \% 11,9'u memnun kalmadıklarını, \% $39,5^{\prime} i$ ise kısmen memnun kaldıklarını belirtmişlerdir. Ilıca'daki termal tedavilerin değerlendirmesi yapılırken katılımcıların $\% 11,5^{\prime} i$ termal tedavinin tıp tedavisine alternatif bir tedavi oluğunu, \%43,6 tıbbi bir tedavi türü olduğunu, \%30'u tıp tedavisinden farklı bir tedavi biçimi olduğunu, $\% 14,8^{\prime} i$ ise tıbbi tedavi ile karşılaştırılmasının doğru olmadığını ifade etmişlerdir (Tablo 10). Katılımcıların büyük oranda yani \%88,1 llıca'dan memnun kaldıklarını ve Ilıca'yı tavsiye edebileceklerini \%90,1 ifade etmeleri, yörenin doğru planlama yapıldığı taktirde gelecekte daha hızı gelişebileceğinin göstergesi olması bakımından önemlidir.

Tablo 10. Katılımcıların kaplıcayı tavsiye etme, memnun kalma durumu ve tedavilerin değerlendirilmesi.

Table 10. Participants' recommendation status, satisfaction condition and evaluation of treatment status.

\begin{tabular}{|l|l|l|}
\hline Tavsiye durumu & $\mathbf{n}$ & $\mathbf{\%}$ \\
\hline Evet & 165 & 67,9 \\
\hline Hayır & 24 & 9,9 \\
\hline Kısmen & 54 & 22,2 \\
\hline Toplam & 243 & 100,0 \\
\hline Memnun kalma durumu & $\mathbf{n}$ & $\%$ \\
\hline Evet & 118 & 48,6 \\
\hline Hayır & 29 & 11,9 \\
\hline Kısmen & 96 & 39,5 \\
\hline Toplam & 243 & 100,0 \\
\hline Tedavilerin değerlendirilmesi & $\mathbf{n}$ & $\mathbf{\%}$ \\
\hline Alternatif bir tedavi & 28 & 11,5 \\
\hline Tıbbi tedavi & 106 & 43,6 \\
\hline Farklı bir tedavi & 73 & 30,0 \\
\hline Tıbbi tedavi ile karşılaştırılmamalı & 36 & 14,8 \\
\hline Toplam & 243 & 100,0 \\
\hline
\end{tabular}

Araştırmaya katılanlar Ilıca'ya gelirken ulaşımlarını \% 74,1 ile özel araç ve \%25,9 ile otobüsle sağlamaktadırlar (Tablo 11). Yörede herkese hizmet veren ve daha sık aralıklarla yola çıkan modern ulaşım araçlarının kullanılması, özel aracı olmayan maddi imkânları kısıtlı insanların da llıca'ya daha sık gelmelerini sağlayacak olması açısından önemlidir.

Katılımcıların \% 7'si bireysel olarak ,\% 28,4'ü arkadaşları ile $\% 64,6^{\prime}$ sı ise aileleri ile Ilıca'ya gelmeyi tercih etmişler- dir. Katılımcıların \%64,6'sının yöreye aileleri ile gelmeyi tercih etmiş olmaları, yörede hala aile bağlarının güçlü olduğu bir kültürün yaşadığını göstermesi bakımından önemlidir.

Tablo 11. Katılımcıların kaplıcaya ulaşım şekli ve kiminle gidildiği.

Table 11. Participants' transportation conditions, and coming with whom to destination area.

\begin{tabular}{|l|l|l|}
\hline Ulaşım şekli & \multicolumn{1}{|c|}{$\mathbf{n}$} & \multicolumn{1}{c|}{$\%$} \\
\hline Özel araç & 180 & 74,1 \\
\hline Otobüs & 63 & 25,9 \\
\hline Toplam & 243 & 100,0 \\
\hline Kiminle geldiniz & $\mathbf{n}$ & $\mathbf{\%}$ \\
\hline Bireysel & 17 & 7,0 \\
\hline Arkadaş & 69 & 28,4 \\
\hline Aile & 157 & 64,6 \\
\hline Toplam & 243 & 100,0 \\
\hline
\end{tabular}

Katılımcılar Ilıca'da alt yapı problemlerinin olup olmadığıyla ilgili sorular sorulduğunda \%20,2'si evet, \% 38,3'ü hayır, \%41,6'sı ise kısmen olduğu şeklinde cevap ermişlerdir (Tablo 12). Toplamda katılımcıların \%62,8'inin Ilıca'da alt yapı problemlerinin olduğunu belirtmesi, yörede en kısa sürede gerek Belediye gerekse diğer kurum ve kuruluşlar tarafından gerekli düzenlemelerin ve yatırımların yapılmasını zorunlu kılmaktadır.

Tablo 12. Katılımcıların Ilıca'da alt yapıyla ilgili değerlendirmeleri, Ilıca'nın tanıtım durumu ve boş zamanlarını değerlendirme şekilleri.

Table 12. Participants' infrastructure, advertisement status and leisure time shapes in llıca.

\begin{tabular}{|l|l|l|}
\hline Alt yapı durumu & $\mathbf{n}$ & $\mathbf{\%}$ \\
\hline Evet yeterli & 49 & 20,2 \\
\hline Hayır yetersiz & 93 & 38,3 \\
\hline Kısmen yeterli & 101 & 41,6 \\
\hline Toplam & 243 & 100,0 \\
\hline Tanıtım durumu & $\mathbf{n}$ & $\mathbf{\%}$ \\
\hline Evet yeterli & 45 & 18,5 \\
\hline Hayır yetersiz & 121 & 49,8 \\
\hline Kısmen yeterli & 77 & 31,7 \\
\hline Toplam & 243 & 100,0 \\
\hline Boş zamanı değerlendirme & $\mathbf{n}$ & $\%$ \\
\hline Kitap okuma & 4 & 1,6 \\
\hline Gazete okuma & 17 & 7,0 \\
\hline Yürüyüş & 62 & 25,5 \\
\hline TV seyretme & 3 & 1,2 \\
\hline Gezi & 8 & 3,3 \\
\hline Alışveriş yapma & 14 & 5,8 \\
\hline Dinlenme & 135 & 55,6 \\
\hline Toplam & 243 & 100,0 \\
\hline
\end{tabular}

Ilıca'nın yakın ve uzak bölgelerde tanıtım durumunun değerlendirilmesinde katılımcıların \%18,5'i llıca'nın tanıtımının iyi yapıldığını, \%49,8'i tanıtımının hiç yapılamadığını, \%31,7'si tanıtımının kısmen yapıldığını belirtmiştir (Tablo 12). 
Ilıca (Kahramanmaraş) kaplıcalarının termal turizm odaklı rekreasyon faaliyetleri

Araştırmaya katılanların \%81,5'i Ilıca'nın tanıtımının yeterince yapılmadığı düşüncesinde olmaları gerek Belediye gerekse Kültür ve Turizm Müdürlüğü tarafından en kısa zamanda yörenin tanıtımını yapacak girişimlerde bulunma gerekliliğini ortaya koymaktadır. Katılımcılar, Ilıca'da boş zamanlarını değerlendirme şekillerini \%1,6'sı kitap okuyarak,\% 7'si gazete okuyarak, \%25,5'i yürüyüş yaparak, \%1,2'si televizyon seyrederek,\% 3,3 gezerek, \% 5,8'i alışveriş yaparak, \% 55,6'sı dinlenerek geçirdiklerini belirtmişlerdir (Tablo 12).

\section{SONUÇ}

Araştırma alanını oluşturan Ilıca yerleşmesi ve kaplıcasının durumu elde edilen bulgular doğrultusunda değerlendirildiğinde yörenin rekreasyon faaliyetleri ve termal turizmi açısından önemli bir potansiyele sahip olduğu görülmektedir. Kahramanmaraş kent merkezine fazla uzak olmayan Ilıca yerleşmesinin sahip olduğu termal kaynaklar, doğal bitki örtüsü ve yükseltisine bağlı olarak oluşan iklim özellikleri turizm ve rekreasyon faaliyetlerini destekler niteliktedir. Yöredeki termal kaynaklar değerlendirilmekte ancak kaplıcaya gelenlerin memnuniyet durumu incelendiğinde tesislerin istenilen kalitede olmadığı, buraya gelen insanların termal kürler (günde en çok üç defa banyo ve her banyo süresi 15 dakika) dışında boş vakitlerini geçirebileceği alanların ve aktivitelerin sınırlı olduğu görülmektedir. Bu durum çoğu ziyaretçi için sıkıntılı bir ortam oluşturmaktadır. Katılımcıların \%75'inden fazlasının 25-60 yaş arası ve \%50'den fazlasının lise ve üniversite mezunu olması, yalnızca yaşlıların değil orta yaş grubu ve eğitim seviyesi yüksek bireylerin de sağığını iyileştirme, eğlenme ve dinlenme amacıyla yöreye gelmiş olmaları yöre geleceği için önem taşımaktadır.

Katılımcıların memnuniyet durumu incelendiğinde $\% 81,5$ gibi büyük bir oranının üç defadan daha fazla yöreye gelmiş olmaları, \%42,8'inin 3-7 gün kalmaları ve \%90'ının Ilıca'yı tavsiye edebileceklerini ifade etmeleri, memnuniyet derecelerini göstermesi bakımından önemlidir. Çünkü dinlenmek için kaplıcaya gelenlerin oranının diğerlerinden yüksek olması (\%42) insanların burayı yalnızca bir termal tesis değil aynı zamanda bir rekreasyon alanı olarak algıladıklarını göstermektedir

Katılımcıların \%45'den fazlası Kahramanmaraş'tan, $\% 74,1$ 'i özel aracıyla ve \%64,6'sı aileleri ile Ilıca'ya gelmiştir. Bu durum yörenin Kahramanmaraş merkeze yakın olması ve yörede hala aile bağlarının güçlü olması ile ilgilidir. Ayrıca llıca'da termal suyun özelliğinin yanı sıra yakınlık, akraba evlerinin bulunması ve iklim özelliklerinin tercih için daha ön sıralarda olması tatil anlayışından ve termal suyun tanıtımının yetersiz olmasından kaynaklanmaktadır.

Yörede kalitesi yüksek termal tesislerin kurulması, rekreasyon için yeni alan ve aktivitelerin oluşturulması gerekmektedir. Bu doğrultuda yeşil alanlar, yürüme parkurları, çadırlı kamping alanları, spor tesisleri, yüzme havuzları, eğlence merkezleri, dinlenme ve piknik alanları ile insanların sohbet edip iletişim kurabilecekleri mekanlar inşa edil- melidir. Bu tür alanların oluşturulmasıyla termal tedaviye ihtiyacı olmayan insanların da dinlenmek ve eğlenmek amacıyla yöreyi ziyaret etmesi sağlanmış olacaktır. Böylece yöre daha cazip hale gelecek, ziyaretçilerin memnuniyet derecesi artacak ve aynı zamanda yöre insanı daha çok ekonomik kazanç elde edebilecektir.

Bilindiği üzere kaplıcalar genellikle termal turizm kapsamında değerlendirilmektedir. Ancak çoğu kaplıcada kür anlayışından uzak, günübirlik ziyaretler ön planda olmaktadır. Bundan dolayı yöre sadece kaplıca amaçlı değil SPA (Salus Per Aquam) amaçlı da kullanılarak, gelir durumu yüksek turist gruplarına hizmet verebilecek bir duruma getirilmelidir. Ayrıca yörenin daha çok ziyaretçi çekebilmesi için alt yapı bağlamında rekreasyon aktivitelerini içeren modern konaklama tesislerinin yapımına ihtiyacı vardır.

Kahramanmaraş ile llıca arasında var olan ulaşım sisteminin daha düzenli hale getirilmesi, toplu ulaşım araçları ve sefer sayılarının arttırılması gerekmektedir. Böylece yörenin kaynaklarından daha fazla kişinin istifade etmesi sağlanmış olacaktır.

Yörenin tanıtımı konusunda reklam faaliyetlerinin yapılması çok önemlidir. Belediye ve İ Kültür ve Turizm Müdürlüğü tarafından bu konudaki tanıtıcı broşür, yayın ve istatistikî veri çalışmalarına ağırlık verilmesi gerekmektedir. Bu bağlamda gerek Belediye gerekse Kültür ve Turizm Müdürlüğü tarafından gerekli tanıtımlar yapılmalıdır.

llıca ve çevresinde mevcut durum tespiti yapılıp bölge jeofizik ve jeokimyasal açıdan değerlendirilerek ihtiyaç durumunda ilave kuyular açılabilmelidir.

Yörede termal kaynaklardan yararlanmanın sürdürülebilir bir şekilde olması, doğanın ekolojik dengesinin korunmasına bağlı olduğu unutulmamalı, bu çerçevede llıca ve çevresindeki doğal çevre ve tarihi değerler, doğal ve kültürel özelliklerini kaybetmeyecek bir şekilde ziyaretçilere tanıtılmalıdır. Böylece daha geniş bir ziyaretçi kitlesinin yöreyi tanıması sağlanmış olacaktır.

Tüm bu hedeflere ulaşabilmek için Ilıca'daki yerli halkın ve işletmelerde çalışan personelin turizm bilinci ve eğitim düzeyinin artırılması sağlanmalı, ziyaretçi memnuniyetine ağırlık verilmelidir.

\section{KAYNAKLAR}

Alaeddinoğlu, F., Can, A.S. ve Yılmaz. E. (2011). Van Gölü Havzası Batı Kesiminde Ekoturizm Potansiyel Kaynakların Derecelendirilmesi ve Turist Profilinin Belirlenmesi, Elvan Yayınları, Ankara.

Aslan, Z. (1993). "Türkiye"de Turizmin Arz ve Talebi". Türkiye Kalkınma Bankası Turizm Yıllığı 1993, Ankara, 39- 50.

Bulut, İ. ve Girgin, M. ( 2001). "Bingöl Kös Kaplıcalarının Coğrafi Etüdü”, Doğu Coğrafya Dergisi, Sayı 5, 59-81.

Çakar, M. (1996). Kahramanmaraş ve Çevresindeki Şifalı Suların Özelliklerinin Araştırılması, K.S.Ü. Fen Bil. Enst., Yüksek Lisans Tezi (Yayımlanmamış), Kahramanmaraş 
Çetin, T. (2011). "Termal Turizm Potansiyeli Açısından Kozaklı (Nevşehir) Kaplıcaları", Turkish Studies International Periodical For The Languages terature and History of Turkish or Turkic Volume 6/1 Winter 2011, Turkey.

Dirisu, N,Ş. (1952). Idroloji (İçme ve kaplıca tedavisi). Ankara Üniv.Tıp Fak.Yay.No:28, Akın Matbaası, Ankara.

Doğanay, H. (1990). Türkiye Turizm Coğrafyası, Erzurum: 128- 135.

Doğanay, H. (1992 ). "Kurşunlu Termal Turistik Bölgesi”, Türkiye Kalkınma Bankası Turizm Yıllığı, 77-96, Ankara.

Doğanay, H. (2001). Türkiye Turizm Coğrafyası, Çizgi Kitabevi, Konya.

Doğaner, S. (2001). Türkiye Turizm Coğrafyası, Çantay Kitabevi, 1. Baskı, İstanbul.

Emekli, G. (2006). "Coğrafya, Kültür ve Turizm: Kültürel Turizm", Ege Coğrafya Dergisi, Sayı 15, 51-59, İzmir.

Erdoğan, E. ve Aklanoğlu, F. (2008). "Termal Turizm ve Afyon Gazlıgöl Örneği", E-Journal of New World Sciences Academy, Vol:3, Number:1, pp.83-92.

Ekiz, D. (2003). Eğitimde Araştırma Yöntem ve Metotlarına Giriş: Nitel, Nicel Ve Eleştirel Kuram Metodolojileri, Anı Yayıncılık, Ankara.

Gül, M., Darbaş, G. ve Gürbüz, K.. (2005). “Alacık Formasyonunun (En Geç Orta Eosen-Erken Miyosen) K. Maraş Havzası İçindeki Tektono-Stratigrafik Konumu" Istanbul Üniversitesi Mühendislik Fakültesi Yerbilimleri Dergisi, Cilt18, Sayı 2, 183-197.

Gürbüz M. ve Korkmaz H. (2001). "Ilıca Kasabasında Sağlık (Termal) Turizmi”, Türk Coğrafya Dergisi, Sayı 36, 87104.

Güzel, A., Çiftçi, C. ve Atay, Y. (2013). "Kaplıca Turizmi Potansiyeli Açısından Şanlıurfa Karaali Kaplıcası", The Journal of Academic Social Science Studies, International Journal of Social Science, Volume 6, Issue 7, p. 513-535, July.

Ibret, Ü. (2007). "Türkiye"de Yeni Gelişen Bir Termal Turizm Merkezi: Çavundur Kaplıcası", Doğu Coğrafya Dergisi, Cilt.12, Sayı.18, 135-163.

İlban, M.O. ve Kaşlı, M. (2009). Termal Turizmin Gelişmesini Etkileyen Sorunları Belirlemeye Yönelik Gönen'de Bir Araştırma, Ege Akademik Bakış / Ege Academic Review, 9 (4): 1275-1293

Kahramanmaraş Valiliği Yatırım İzleme ve Koordinasyon Başkanlığı (YíOB). (2014). Doğal Kaynaklar, Ruhsat ve Kültür Varlıkları Müdürlüğü, Kahramanmaraş.

Kaya, M. (2003). "Türkiye ve Eskişehir"in Termal Maden Suyu Potansiyeli ve Sorunları", Eskişehir Ticaret Odası Dergisi, Cilt 20, Sayı 87, 11-13.

Lund, W.J. ve Freeston, H.D. (2001). " World-Wide Direct Uses of Geothermal Energy 2000", Geothermics, Sayı $30,29-68$.

Özgen, N. (2010). “Doğu Anadolu Bölgesi"nin doğal turizm potansiyelinin belirlenmesi ve planlamaya yönelik öneriler". Uluslararası Insan Bilimleri Dergisi, Cilt 7, Sayı 1, 1385-1416.

Özgüç, N. (1998). Turizm Coğrafyası- Özellikler Bölgeler. Çantay Kitabevi, İstanbul.
Özgüç, N. (2007). Turizm Coğrafyası. Çantay Kitabevi, İstanbul.

Pırnar, i. (2008). Termal ve Sağlık Turizmi, Ege Fikir Önderleri, Sektörel Etki Analizleri, Ege Ekonomiyi Geliştirme Vakfı, Denizli.

Sayılı, M., Akça, H., Duman, T., ve Esengun, K.. (2007). "Psoriasis Treatment Via Doctor Fishes As Part of Health Tourism: A Case Study of Kangal Fish Spring, Turkey." Tourism Management, 28, pp. 625-629.

Soykan, F. ( 2003). "Kırsal Turizm ve Türkiye Turizmi İçin Önemi". Ege Coğrafya Dergisi, Cilt 12, Sayı 1, 1-11.

Söylemez, F. (2007). "XVIII. Yüzyıl Başlarından XIX. Yüzyıl Ortalarına Kadar Maraş ve Çevresinde Eşkıyalık Hareketleri", Erciyes Üniversitesi Sosyal Bilimler Enstitüsü Dergisi, Sayı: 22, 69-85.

Taşlıyan, M. ve Arı, N. Ü. (2012). Bölgesel Kalkınma Potansiyelinin Harekete Geçirilmesinde Sağlık Sektörünün Yeri Üzerine Bir Araştırma, II. Bölgesel sorunlar ve Türkiye Sempozyumu 1-2 Ekim

Tıraş, M. (2003). "Haruniye Kaplıcaları”, Türk Coğrafya Dergisi, Sayı 43, 97-109.

Tuncel, M. ve Doğaner, S. (1992), “Kütahya'da Kaplıca Turizmi", Ege Coğrafya Dergisi, 47-60.

Türksoy, A ve Türksoy, S.S. (2010). Termal Turizmin Geliştirilmesi Kapsamında Çeşme ilçesi Termal Kaynaklarının Değerlendirilmesi, Ege Akademik Bakış / Ege Academic Review 10 (1) 2010: 699-725

Ülker, i. (1988). Türkiye'de Sağlık Turizmi ve Kaplıca Planlaması, Kültür ve Turizm Bakanlığı Yayınları; 1006, Ankara.

Yıldız, Z. (2006). Turizmin Bölgesel Kalkınmaya Sağladığı Katkılar ve Göller Bölgesi Uygulaması, Doktora Tezi, İstanbul Üniversitesi SBE, İstanbul.

Zengin, M., Gürbüz, M. ve Oğuz, H. (2013). Göksun Ilçcesinin Turizm Potansiyeli, Gazi Kitabevi, Ankara.

\section{Internet Kaynakları:}

http://www.ekodialog.com, 2010.

http://www.ekodialog.com/Turkiye_ekonomi/turkiyenin_k aplica_maden_sulari (erişim: 19.02.2013)

http://www.ilica.bel.tr- Şubat 2014

http://www.mgm.gov.tr, 2015- (erişim:30.05.2015)

http://www.turizm.gov.tr (erişim: 10.10.2013). 